\title{
Proteomic Analysis of
} Paracoccidioides brasiliensis During Infection of Alveolar Macrophages Primed or Not by Interferon-Gamma

Edilânia Gomes Araújo Chaves ${ }^{1 \dagger}$, Juliana Alves Parente-Rocha ${ }^{1 \dagger}$,
Lilian Cristiane Baeza
Milton Adriano Pelli de Oliveira'le Silva Araújo ${ }^{1}$, Clayton Luiz Célia Maria de Almeida Soares ${ }^{1 *}$

${ }^{1}$ Laboratório de Biologia Molecular, Instituto de Ciências Biológicas, Universidade Federal de Goiás, Goiânia, Brazil, ${ }^{2}$ Centro de Ciências Médicas e Farmacêuticas, Universidade Estadual do Oeste do Paraná, Cascavel, Brazil, ${ }^{3}$ Instituto de Patologia Tropical e Saúde Pública, Universidade Federal de Goiás, Goiânia, Brazil
OPEN ACCESS

Edited by:

Carlos Pelleschi Taborda

University of São Paulo, Brazil

Reviewed by:

Allan J. Guimaraes,

Universidade Federal Fluminense,

Brazil

Sandro Rogerio Almeida,

University of São Paulo, Brazil

*Correspondence:

Célia Maria de Almeida Soares

cmasoares@gmail.com

tThese authors have contributed equally to this work

Specialty section: This article was submitted to Fungi and Their Interactions,

a section of the journal

Frontiers in Microbiology

Received: 27 September 2018

Accepted: 16 January 2019

Published: 05 February 2019

Citation:

Chaves EGA, Parente-Rocha JA, Baeza LC, Araújo DS, Borges CL, Oliveira MAPd and Soares CMA (2019) Proteomic Analysis of Paracoccidioides brasiliensis During Infection of Alveolar Macrophages Primed or Not by Interferon-Gamma.

Front. Microbiol. 10:96. doi: 10.3389/fmicb.2019.00096
Although members of the Paracoccidioides complex are not obligate intracellular pathogens, they present the ability to survive and multiply inside epithelial cells and phagocytes of mammals, which may favor the spread of the fungus in host tissues. Macrophages resident in the lung are the first line of defense against paracoccidioidomycosis (PCM), presenting mechanisms to control the pathogen dissemination through the granuloma formation or eliminating the fungus through phagocytosis. Phagocytosis triggers an oxidative burst, in which there is an increase in the production of toxic elements, derived from oxygen and nitrogen. The interior of the phagolysosome is a harsh environment to the internalized pathogens, since in addition to the oxygen and nitrogen reactive species, microorganisms face nutrient shortages and proteases activity. Through the NanoUPLC-MSE ${ }^{E}$ technology, we analyzed the proteomic response of Paracoccidioides brasiliensis during the infection of alveolar macrophages primed or not by interferon gamma (IFN- $\gamma$ ). At 6 hs post-infection, only (IFN- $\gamma$ )-primed macrophages were able to kill the fungus. We observed the regulation of amino acids degradation, tricarboxylic acid cycle, respiratory chain, ATP synthesis, glyoxylate cycle, as well as an increase in the expression of defense proteins related to oxidative stress, heat shock, and virulence factors under both conditions analyzed. However, some pathways described as essential for the survival of pathogens inside macrophages were observed only or with higher intensity in yeast cells recovered from non-primed macrophages, as phosphate pentoses pathway, methylcitrate cycle, synthesis of cell wall components, and mitochondrial activity. The data indicate that the intracellular environment of non-primed macrophages could be more permissive to the survival and multiplication of $P$. brasiliensis. The identification of key molecules for the establishment of infection can help the understanding of the nature of the parasite-host relationship and pathogenesis of PCM.

Keywords: Paracoccidioides spp., proteome, metabolism, oxidative stress, alveolar macrophages, interferon gamma 


\section{INTRODUCTION}

Paracoccidioidomycosis (PCM) is a systemic granulomatous mycosis caused by thermodimorphic fungi of the genus Paracoccidioides. This genus comprises five species, as following: Paracoccidioides brasiliensis, Paracoccidioides americana, Paracoccidioides restrepiensis, Paracoccidioides venezuelensis, and Paracoccidioides lutzzi (Matute et al., 2006; Carrero et al., 2008; Teixeira et al., 2009; Munoz et al., 2016; Turissini et al., 2017). PCM is an endemic disease of South America that currently infects at least 10 million people (Martinez, 2017; Turissini et al., 2017). The fungus mainly attacks the lungs, since the infection occurs through inhalation of infectious conidia or mycelia propagules. In few hours after contact with the pulmonary tissue, the fungus converts to the yeast phase, its parasitic form (McEwen et al., 1987). One of the main features of PCM is the formation of granulomas, since macrophages are one of the primary defense elements against Paracoccidioides. Macrophages form a giant multinucleated agglomerate capable of limiting the spread of yeast cells, besides eliminating the pathogens through phagocytosis (McEwen et al., 1987; Brummer et al., 1989; Fortes et al., 2011).

The intracellular environment of macrophages is a challenge for fungal survival. In addition to the low availability of nutrients and the action of proteases, there is an explosion of oxygen consumption during host-pathogen interaction (HPI), which has been associated with the microbicidal activity of phagocytes (Philippe et al., 2003; Fang, 2004; Haas, 2007). This reaction produces large amounts of the reactive oxygen species (ROS) and reactive nitrogen species (RNS). The oxidative and nitrosative stresses cause oxidation of proteins, lipids, and DNA which interferes in the replication of pathogens (Ferrari et al., 2011; Fang, 2004). Despite this, Paracoccidioides is able to survive and multiply inside phagocytes of mammals, which indicates that the fungus can subvert the phagocytic defenses to promote its spread through host tissues (Brummer et al., 1989; Moscardi-Bacchi et al., 1994; Hanna et al., 2000; Mendes-Giannini et al., 2004).

The intracellular survival of fungi has motivated several studies to investigate which are the strategies used by those pathogens to survive inside macrophages (Seider et al., 2010; Seider et al., 2014; Kasper et al., 2015; Erwig and Gow, 2016; Camacho and Nino-Vega, 2017). Proteomic and transcriptomic studies analyzed the metabolic adaptation of fungi to in vitro conditions of deprivation of carbon sources, mimicking the interior of the phagolysosome (Yin et al., 2004; Askew et al., 2009; Szilagyi et al., 2013; Lima et al., 2014; Baeza et al., 2017). Those studies show that fungi, including Paracoccidioides, present a metabolic reprogramming decreasing glycolysis and increasing alternative carbon pathways as glyconeogenesis, amino acid degradation, $\beta$-oxidation of fatty acids, and glyoxylate cycle. Corroborating transcriptional and proteomic data, it was observed that fungal strains presenting disrupted genes encoding proteins in those pathways have attenuated virulence during macrophage infection (Lorenz and Fink, 2002; Ramirez and Lorenz, 2007).
The success of mechanisms of intracellular evasion of pathogens depends on the activation profile of macrophages. Activation of phagocytes with INF- $\gamma$ affects directly the viability of Paracoccidioides sp. cells interacting with macrophages, and is crucial to prevent the progression of disease. Infection assays performed with several members of the Paracoccidioides complex showed that the addition of INF- $\gamma$ does not increase the phagocytosis index, but it confers microbicide activity to the macrophages in a dose-dependent manner (Brummer et al., 1989; Moscardi-Bacchi et al., 1994; Rodrigues et al., 2007). Moreover, deficiency in the immune system, related to low production of cytokines, have been associated with the evolution of PCM. Studies revealed that the production of IL- 2 and INF- $\gamma$ by peripheral blood mononuclear cells from patients affected by acute or chronic PCM was lower compared to healthy patients. INF- $\gamma$ also plays an important role in the recruitment of defense cells to the lungs and for the efficiency of granulomas. Large amounts of IFN- $\gamma$ were detected in compact granulomas of PCMresistant mouse in relation to loose granulomas and multifocal lesions detected in susceptible animals (Souto et al., 2000, 2003; Bernard and Latge, 2001; Nishikaku et al., 2011).

To our knowledge, up-to-date, proteomic analysis of Paracoccidioides phagocytosed by macrophages with different activation patterns has not been performed. Previous studies from our group analyzed the proteomic response of Paraccidioides to macrophage interaction after $24 \mathrm{~h}$ and described modulation of energetic metabolism and of proteins related to stress response. The down-regulation of glycolysis and TCA cycle was observed and the up-regulation of ethanol production and fatty acid degradation occurs, suggesting the fungus preferentially uses anaerobic pathways to obtain energy. The up-regulation of proteins related to cell rescue and virulence, such as proteases and superoxide dismutases (SODs), are also described suggesting that this repertoire is required to Paracoccidioides survival inside macrophages (Parente-Rocha et al., 2015).

In this study, we compared the proteomic response of $P$. brasiliensis, $\mathrm{Pb} 18$ during interaction with alveolar macrophages, primed or not with INF- $\gamma$. Metabolic peculiarities between the two conditions, such as the activation of pentosephosphate pathway, methylcitrate cycle, synthesis of cell wall components, and intense mitochondrial activity, were observed only in fungal cells recovered from non-primed macrophages. In both analyzed conditions, the fungus presented decrease of $\beta$-oxidation of fatty acids and protein synthesis, and increase in enzymes related to amino acid degradation, TCA and glyoxylate cycles, as alternative energy pathways, at $6 \mathrm{~h}$ post infection. The induction of proteins related to heat shock response, antioxidant response, and accumulation of virulence factors, were observed, predominantly in yeast cells after interaction with non-primed macrophages. While the primed cells showed fungicidal activity in the first $6 \mathrm{~h}$ of interaction, the interior of non-primed macrophages appears to be a favorable environment to the survival and multiplication of $P$. brasiliensis. When considering primed macrophages, the same metabolic pathways were induced comparing to the control, but at low levels than those observed in $P$. brasiliensis recovered from non-primed 
macrophages, suggesting that the primed macrophages difficult the fungus adaptation to survival. The identification of key molecules for the establishment of infection can help us to understand the nature of the parasite-host relationship and the factors that determine the evolution from asymptomatic infection to manifested disease.

\section{MATERIALS AND METHODS}

\section{Cultivation and Maintenance of Microorganism}

Paracoccidioides brasiliensis, Pb18 (chronic PCM; São Paulo, Brazil; P. brasiliensis, Pb18) (Turissini et al., 2017) was used in all experiments. The yeast cells were maintained by sub culturing at $36^{\circ} \mathrm{C}$ in Fava Netto's solid medium every 7 days (Fava-Netto, 1955). After this period, the cells were transferred to Fava Netto's liquid medium for $72 \mathrm{~h}$ at $36^{\circ} \mathrm{C}$ under agitation at $150 \mathrm{rpm}$ and used to perform the experiments.

\section{Cultivation and Maintenance of Alveolar Macrophages}

The alveolar macrophages AMJ2-C11 (Rio de Janeiro Cell Bank - BCRJ/UFRJ, accession number 0039) are originated from Mus musculus. The cells were maintained in DMEM medium (Vitrocell Embriolife, Campinas, São Paulo, Brazil) containing bovine fetal serum $10 \%(\mathrm{v} / \mathrm{v})$ at $36^{\circ} \mathrm{C}$ and $5 \% \mathrm{CO}_{2}$. The culture medium was changed after the cells reach complete confluence.

\section{Macrophage Infection Assays}

Paracoccidioides brasiliensis, Pb18 infection in AMJ2-C11 alveolar macrophages was performed in triplicates on 12-well polypropylene plates. In each well was plated a total of $10^{6}$ macrophages cells in DMEM medium containing or not IFN- $\gamma$ (1 U/mL) (Sigma-Aldrich, St. Louis, MO, United States) and bovine fetal serum $10 \%(\mathrm{v} / \mathrm{v})$. The plates were incubated for $12 \mathrm{~h}$ at $36^{\circ} \mathrm{C}$ and $5 \% \mathrm{CO}_{2}$ until complete confluence. The medium was removed and a fresh DMEM medium containing or not IFN- $\gamma(1 \mathrm{U} / \mathrm{mL})$ and bovine fetal serum $10 \%(\mathrm{v} / \mathrm{v})$ plus $5 \times 10^{6}$ $\mathrm{Pb} 18$ cells were added to the macrophages. For all infection assays, the yeast cells obtained from a $72 \mathrm{~h}$ inoculum in Fava Netto's liquid medium were passed through $0.70 \mu \mathrm{m}$-pore membrane filters, with the aid of syringe and needle. The plates were incubated at $36^{\circ} \mathrm{C}$ and $5 \% \mathrm{CO}_{2}$ during 3, 6, 9, and $12 \mathrm{~h}$. The wells were gently washed three times with sterile phosphate-buffered saline (PBS) and the macrophages were lysed by the addition of sterile water. The yeast cells were recovered by centrifugation at $8,000 \times g$ for $10 \mathrm{~min}$ (ParenteRocha et al., 2015). The pellet was diluted (1:100) and plated in solid brain heart infusion (BHI) medium, supplemented with bovine fetal serum $4 \%(\mathrm{v} / \mathrm{v})$ and glucose $4 \%(\mathrm{v} / \mathrm{v})$. Yeast cells viability was evaluated based on the number of colony-forming units (CFU), determined after growth at $36^{\circ} \mathrm{C}$ for 10 days. The control was obtained by incubating $5 \times 10^{6}$ cells $/ \mathrm{mL}$ in DMEM medium, added of bovine fetal serum $10 \%(\mathrm{v} / \mathrm{v})$ for $6 \mathrm{~h}$ at $36^{\circ} \mathrm{C}$ and $5 \% \mathrm{CO}_{2}$. Control fungal cells were washed with sterile water prior to protein extraction. Obtainment of adhered and internalized fungal cells indexes after interaction with primed and non-primed macrophages were performed by counting a total of 600 events (macrophages) in cover lips stained with Giemsa, as previously described (Gori and Scasso, 1994).

\section{Obtaining Protein Extracts}

The proteomic analysis was carried out after $6 \mathrm{~h}$ post interaction of fungal and macrophage cells. Fungal protein extracts were obtained in biological triplicates from the three conditions to be analyzed: $P b 18$ cells recovered of primed macrophages ( $\left.P b 18 \_\mathrm{P}\right)$; Pb18 cells recovered of non-primed macrophages ( $P b 18 \_N P$ ) and control cells ( $\mathrm{Pb} 18$ cells not interacting with macrophages). The yeast cells were collected by centrifugation at $8,000 \times g$ for $10 \mathrm{~min}$ and washed once with RapiGEST SF Surfactant $0.1 \%(\mathrm{v} / \mathrm{v})$ (Waters Corporation, Billerica, MA, United States), followed by washing with ultrapure water and PBS $1 \times$, in order to remove any contamination of the macrophage cells (Parente-Rocha et al., 2015; Pigosso et al., 2017). The pellet was ressuspended in extraction buffer (20 mM Tris- $\mathrm{HCl}, \mathrm{pH} 8.8$, and $2 \mathrm{mM} \mathrm{CaCl}_{2}$ ) and distributed in tubes containing glass beads (Sigma-Aldrich, St. Louis, MO, United States) in equal volume of the material. The suspension was processed on ice in BeadBeater equipment (BioSpec, Products Inc., Bartlesville, OK, United States) during three cycles of $30 \mathrm{~s}$. The cell lysate was centrifuged at 10,000 $\times g$ during $15 \mathrm{~min}$ at $4^{\circ} \mathrm{C}$ and the protein content in the supernatant was quantified using the Bradford reagent (Sigma-Aldrich, St. Louis, MO, United States) using bovine serum albumin (BSA) as standard.

\section{Protein Digestion for NanoUPLC-MSE Analysis}

Proteins were enzymatically digested with tripsin as described previously, with some modifications (Murad et al., 2011). Briefly, a total of $150 \mu \mathrm{g}$ of protein (previous item) of each sample was added to $10 \mu \mathrm{L}$ of $50 \mathrm{mM}$ ammonium bicarbonate, $\mathrm{pH} 8.5$, in a microcentrifuge tube. Next, $75 \mu \mathrm{L}$ of RapiGEST $^{\mathrm{TM}}$ SF Surfactante $(0.2 \% \mathrm{v} / \mathrm{v})$ (Waters Corporation, Billerica, MA, United States) was added and the sample was vortexed and incubated in a dry bath at $80^{\circ} \mathrm{C}$ for $15 \mathrm{~min}$. In each sample were added $2.5 \mu \mathrm{L}$ of $100 \mathrm{mM}$ dithiothreitol (GE Healthcare, Piscataway, NJ, United States), at $60^{\circ} \mathrm{C}$ for $30 \mathrm{~min}$, while cysteines were alkylated by the addition of $2.5 \mu \mathrm{L}$ of $300 \mathrm{mM}$ iodoacetamide (GE Healthcare, Piscataway, NJ, United States) for $30 \mathrm{~min}$, at room temperature in the dark. The digestion of proteins was performed by the addition of $30 \mu \mathrm{L}$ of trypsin $0.05 \mu \mathrm{g} / \mu \mathrm{L}$ (Promega, Madison, WI, United States) at $37^{\circ} \mathrm{C}$, in dry bath, for $16 \mathrm{~h}$. Then, $30 \mu \mathrm{L}$ of trifluoroacetic acid (TFA) solution 5\% (v/v) was added to the samples, followed by incubation for $90 \mathrm{~min}$ at $37^{\circ} \mathrm{C}$, for digestion stop, and precipitation of the RapiGEST reagent. The samples were centrifuged at $18,000 \times g$ for $30 \mathrm{~min}$ and the supernatant was transferred to a new tube and dried in a speed vacuum (Eppendorf, Hamburg, Germany) for $2 \mathrm{~h}$. The pellet containing peptides was suspended in $80 \mu \mathrm{L}$ of a solution 
containing $20 \mathrm{mM}$ of ammonium formiate and $150 \mathrm{fmol} / \mu \mathrm{L}$ of PHB (Rabbit Phosphorylase B) (Waters Corporation, Billerica, MA, United States) (MassPREP protein), as internal standard. The tryptic peptides were analyzed using a nanoACQUITY UPLC $^{\circledR}$ M-Class system (Waters Corporation, Billerica, MA, United States) coupled to Synapt G1 MS ${ }^{\mathrm{TM}}$ mass spectrometer (Waters Corporation, Billerica, MA, United States), equipped with a NanoElectronSpray source and two mass analyzers: a quadrupole and a time-of-flight (TOF) operating in the V-mode. Nanoscale LC separation of tryptic peptides was performed with two reverse phase columns. The peptides were separated using a gradient of $11.4,14.7,17.4,20.7$, and $50 \%(\mathrm{v} / \mathrm{v})$ of acetonitrile $/ 0.1 \%(\mathrm{v} / \mathrm{v})$ formic acid, with a flow rate of $2.000 \mu \mathrm{L} / \mathrm{min}$. Data were obtained using the instrument in the $\mathrm{MS}^{E}$ mode, which switches the low energy $(6 \mathrm{~V})$ and elevated energy $(40 \mathrm{~V})$ acquisition modes every $0.4 \mathrm{~s}$. The lock mass was used for calibration of the apparatus, using a constant flow rate of $0.2 \mu \mathrm{L} / \mathrm{min}$ at concentration of $200 \mathrm{fmol}$ protein GFP [Glu $]^{1}$-Fibrinopeptide B human $(m / z$ 785.8426) (Sigma-Aldrich, St. Louis, MO, United States). The samples were analyzed in triplicate, from three independent experiments.

\section{Data Processing and Protein Identification}

Mass spectrometry raw data of peptide fractions were processed using the ProteinLynx Global SERVER (PLGS) platform (Waters Corporation, Billerica, MA, United States). Then, the processed spectra were searched against $P$. brasiliensis, $\mathrm{Pb} 18$ protein sequences together with reverse sequences. The mass error tolerance for peptide identification was under $50 \mathrm{ppm}$. Protein identification criteria were as following: detection of at least two fragment ions per peptide; five fragment ions per protein; the determination of at least one peptide per protein; carbamidomethylation of cysteine as a fixed modification; phosphorylation of serine, threonine, and tyrosine; and oxidation of methionine were considered as variable modifications; maximum protein mass $(600 \mathrm{kDa})$; one missed cleavage site was allowed for trypsin; maximum false positive ratio (FDR) of $5 \%$ was allowed. For the analysis of the level of protein quantification, the observed intensity measures were normalized using a protein that showed lower coefficient of variance between the different conditions analyzed and present in all replicates. Expression ${ }^{E}$ informatics v.3.0.2 was used for proper quantitative comparisons. The identified proteins were organized by the expression algorithm, into a statistically significant list, corresponding to induced and reduced regulation ratios between the different conditions analyzed. The mathematical model used to calculate the ratios was a part of the Expression algorithm inside the PLGS software (Waters Corporation, Billerica, MA, United States) (Geromanos et al., 2009). The minimum repeat rate for each protein in all replicates (nine in total for each condition) was 6 . Proteins that presented $40 \%$ of differences in expression values, when compared among the different conditions, were considered regulated. Tables of peptides and proteins generated by the PLGS were merged, and the data of dynamic range, peptide detection type, and mass accuracy were calculated for each sample, as previously described using the software MassPivot v1.0.1 (Murad and Rech, 2012), FBAT (Lange et al., 2004), Spotfire ${ }^{\circledR}$ v8.0 program (TIBCO software), and Microsoft Excel ${ }^{\circledR}$ (Microsoft) was used for table manipulations. Uniprot $^{1}$ and Pedant on MIPS ${ }^{2}$ database were used for functional classification. NCBI database was employed for annotation of uncharacterized proteins ${ }^{3}$. The heat maps were performed by using MultiExperiment Viewer tool version $4.9^{4}$.

\section{Analysis of Cell Wall Components by Fluorescence Microscopy}

To evaluate the cell wall components glucans, glycosylated proteins, and chitin contents, the yeast cells recovered of macrophages were stained with aniline blue (AB) (Sigma Aldrich, Missouri, United States) for $5 \mathrm{~min}$, concanavalin A (ConA) TYPE VI conjugated to FITC $100 \mu \mathrm{g} / \mathrm{mL}$ (Sigma-Aldrich, St. Louis, MO, United States) for $30 \mathrm{~min}$ and calcofluor white (CFW) $100 \mu \mathrm{g} / \mathrm{mL}$ (Sigma-Aldrich, St. Louis, MO, United States) for $30 \mathrm{~min}$ (de Curcio et al., 2017). These experiments were performed independently for each substance. Stained samples were visualized under a fluorescence microscope (Zeiss Axiocam MRc-Scope A1, Oberkochen, Germany). Images were obtained at bright field, at 340-380 nm for AB, 470-480 nm for Con A, and at 395-440 nm for CFW. A minimum of 100 cells on each microscope slide were used to evaluate fluorescence intensity in triplicates. The AxioVision Software (Carl Zeiss AG, Germany) determined the fluorescence intensity (in pixels) and standard error of each analysis. Statistical comparisons were performed using the Student's $t$-test and $p \leq 0.05$ was considered statistically significant.

\section{Evaluation of Mitochondrial Activity}

Paracoccidioides brasiliensis, $\mathrm{Pb} 18$ yeast cells recovered from macrophages and control cells (as previously described) were centrifuged at $8,000 \times \mathrm{g}$ for $10 \mathrm{~min}$. The pellet was diluted in PBS $1 \times$ to a concentration of $1 \times 10^{6}$ cells $/ \mathrm{mL}$. To label mitochondria, the cells were stained with Mitotracker Green FM (400 nM; Molecular Probes, M7514) for $45 \mathrm{~min}$ at $37^{\circ} \mathrm{C}$. Then, the cells were washed three times with PBS $1 \times$ and labeled with rodhamine $(2.4 \mu \mathrm{M})$ for $45 \mathrm{~min}$ at $37^{\circ} \mathrm{C}$, according to the manufacturer's protocol (Invitrogen, Carlsbad, CA, United States) and washed three times with PBS $1 \times$. Labeled cells were observed under a fluorescence microscope (Zeiss Axiocam MRc-Scope A1, Oberkochen, Germany) and photographed at bright field, and at 450-490 $\mathrm{nm}$ for the Mitotracker and 546$512 \mathrm{~nm}$ for rosamine dye probes. A minimum of 100 cells on each microscope slide were used to evaluate fluorescence intensity in triplicate. The AxioVision Software (Carl Zeiss AG, Germany) determined the fluorescence intensity (in pixels) and standard error of each analysis. Statistical comparisons were performed using the Student's $t$-test and $p \leq 0.05$ was considered statistically significant.

\footnotetext{
${ }^{1}$ http://www.uniprot.org

${ }^{2} \mathrm{http} / / /$ mips.helmholtz-muenchen.de/funcatDB/

${ }^{3}$ https://www.ncbi.nlm.nih.gov/

${ }^{4}$ http://en.bio-soft.net/chip/MeV.html
} 


\section{RESULTS}

\section{P. brasiliensis Survival Into Alveolar Macrophages}

Paracoccidioides brasiliensis, Pb18 infection in AMJ2-C11 alveolar macrophages was performed to determine the best time of infection, with higher rate of internalization/adhrence of viable fungi cells. Times of 3, 6, 9, and $12 \mathrm{~h}$ of infection were analyzed regarding the number of CFUs in $P b 18$ yeast cells recovered of primed macrophages (Pb18_P) and non-primed macrophages (Pb18_NP). Figure 1A shows that the number of viable fungal cells increases inside the primed macrophage until $6 \mathrm{~h}$. After this time, the number of viable fungi decreases in primed macrophages, suggesting killing of yeast cells by the macrophages after $9 \mathrm{~h}$ of interaction. In this way, the proteomic response of P. brasiliensis, after $6 \mathrm{~h}$ of interaction with macrophages, was investigated to analyze the differences in the initial proteomic response of the fungus during interaction with macrophages with different activation patterns. In order to evaluate the index of fungal cells adhered/internalized cover lips stained by Giemsa were analyzed after $6 \mathrm{~h}$ of interaction of fungal cells with primed and non-primed macrophages. The results are shown in Figure 1B. After interaction with non-primed macrophages, $42 \%$ of fungal cells interacting with macrophages are internalized and $58 \%$ are adhered to macrophages. A slight increase in the internalization was observed after interaction of fungal cells with primed macrophages $(48 \%)$ while the percentage of adhered cells index was $52 \%$ after interaction of fungal cells with primed macrophages.

\section{Proteomic Data Quality Analysis}

Protein extracts were obtained in biological triplicates. Protein quantification was performed using Nano-UPLCMS ${ }^{E}$ and the protein and peptide data were generated by the PLGS (Supplementary Figure 1). The false positive rates of proteins obtained from Pb18_P were 3.80\%, Pb18_NP 5.88\%, and control 2.99\%. Those experiments resulted in 53,745; 47,941; and 61,561 identified peptides, from Pb18_P; Pb18_NP; and control, respectively. The values of 50.1, 49.2, and $53.9 \%$ were obtained from peptide match type data in the first pass and 7.5, 7.6, and 9.7\% from the second pass, for Pb18_P, Pb18_NP, and control, respectively. The percentages of 16.2, 16.5, and $14 \%$ of total peptides were identified by a missed trypsin cleavage, whereas an in-source fragmentation was 11, 11.2, and $11.8 \%$ for Pb18_P, Pb18_NP, and control, respectively. The peptides identification within the first and second pass (PepFrag 1 and 2) were predominantly higher than 56\%, and source fragmentation and missed cleavage values did not exceed $20 \%$ in all analyzed conditions (Supplementary Figure 1A; Murad and Rech, 2012). The peptide parts per million errors (ppm) indicated that the majority, 82, 83.9, and $79.3 \%$ of identified peptides, were detected with an error of less than 10 ppm for Pb18_P, Pb18_NP, and control, respectively (Supplementary Figure 1B). The obtained results from dynamic range detection indicated that a 3 -log range concentration and a good detection distribution of high and low molecular weights

\section{A}

\section{Fungal survival}

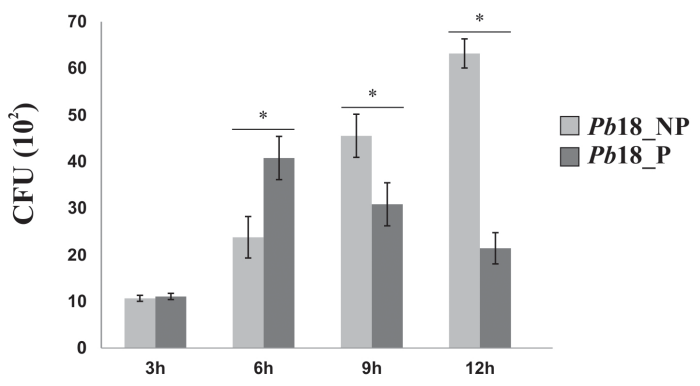

B

Fungal interaction

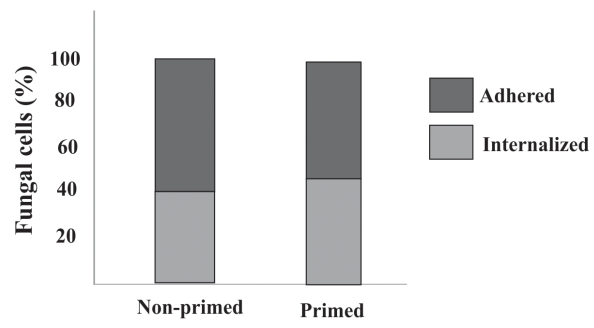

FIGURE $1 \mid P$. brasiliensis, $P b 18$ infection in alveolar macrophages. (A) Recovery of $P$. brasiliensis fungal cells after interaction with primed and non-primed macrophages. P. brasiliensis, $P b 18$ was recovered from AMJ2-C11 primed (Pb18_P) and non-primed (Pb18_NP) alveolar macrophages, by INF- $\gamma$ after: 3, 6, 9, and $12 \mathrm{~h}$ of interaction. The viable yeas cells recovered from macrophages were determined based on the number of CFUs. The error bars indicate the mean \pm standard deviation of the values obtained from the triplicate of independent experiments. *, Significantly different results; $P$-value $\leq 0.05$. (B) Percentage of adhered and internalized fungal cells after interaction with primed and non-primed macrophages. The interaction assay was performed in glass slides; fungi cells were washed, fixed, and stained with Giemsa. A total of 600 macrophages were counted.

were obtained in all analyzed conditions (Supplementary Figure 1C).

Five hundreds and thirty eight proteins were detected, considering the proteomic analysis. The description of all detected proteins is shown in Supplementary Table 1. Supplementary Figure 2 ilustrates this data. Among proteins identified during interaction of fungal cells with primed macrophages, 199 proteins were detected in similar amounts and were considered not regulated proteins. A total of 135 proteins were up-regulated in fungal cells after interaction with primed macrophages. Proteins detected only in yeast cells recovered from primed macrophages, in number of 54 proteins were also considered up-regulated. The down regulated proteins include those detected in higher amounts in the control fungal cells (67 proteins) and proteins detected only in the control condition in number of 34 . The data obtained from fungal cells after interaction with non-primed macrophages include: 140 proteins that were detected in similar amounts in control fungal cells and in yeast cells after interaction with non-primed macrophages, 222 proteins up-regulated in the fungal cells after interaction 
with non-primed macrophages, and 54 proteins detected only after interaction with primed macrophages. Concerning to down regulated proteins, 15 were detected in higher amounts in control fungal cells and 49 proteins were exclusively detected in control fungal cells.

\section{Regulated Proteins in $P$. brasiliensis During Infection of Primed Macrophages}

Protein extracts of $P$. brasiliensis, $P b 18$ recovered of primed macrophages were compared with control samples by using $\mathrm{MS}^{E}$ technology. A total of 290 regulated proteins was detected in Pb18_P; from those 189 were up-regulated proteins and 101 down-regulated proteins (Supplementary Table 2). Supplementary Table 1 shows that after $6 \mathrm{~h}$ of interaction with primed macrophages, $P$. brasiliensis presents accumulation of proteins and enzymes from the TCA cycle, electron transport chain, and ATP synthesis, proteins related to oxidative stress protection, such as thioredoxin reductase (TrxR) (accession number PADG_01551) and SOD (accession number PADG_07418), and virulence factors such as serine proteinase (PADG_07422). Also, potential transcription factors are accumulated. In counterpart, down-regulation of proteins related with the $\beta$-oxidation of fatty acids was described. The regulation of proteins related to the tricarboxylic acid cycle, electron transport chain, ATP synthesis, and oxidation of fatty acids is visualized in the heat map presented in Figure 2.

\section{Proteins Regulated in $P$. brasiliensis During Infection of Non-primed Macrophages}

A total of 340 regulated proteins were detected in $P b 18$ yeast cells recovered from macrophages not incubated with IFN- $\gamma$. From the total, 276 were up-regulated proteins and 64 were down-regulated (Supplementary Table 3). P. brasiliensis, Pb18 cells recovered from macrophages not incubated with IFN- $\gamma$ showed an increase of proteins related to pentose-phosphate pathway, TCA, methylcitrate cycle, electron transport, and ATP synthesis, as well as transcription factors. Molecules related to cell rescue, defense, and virulence are also particularly accumulated. Enzymes of carbohydrate metabolism, related to the synthesis of cell wall precursors, were also induced. The negative regulation of enzymes from beta-oxidation of fatty acids was also described (Supplementary Table 3).

\section{Comparative Analysis of the Proteome of $P$. brasiliensis Recovered From IFN- $\gamma$ Primed and Non-primed Macrophages}

Yeast cells interacting with non-primed macrophages depicted faster metabolic adaptation, activating alternative routes such as methyl citrate cycle, in addition to amino acid degradation, pentose-phosphate pathway, electron transport chain, and ATP synthesis, as depicted in Figure 3. These data indicate that the intracellular environment of primed macrophages presents barriers that may hinder the adaptation of the fungus to the cell environment. Corroborating this hypothesis, Pb18_NP cells present a higher number of proteins and abundance of enzymes

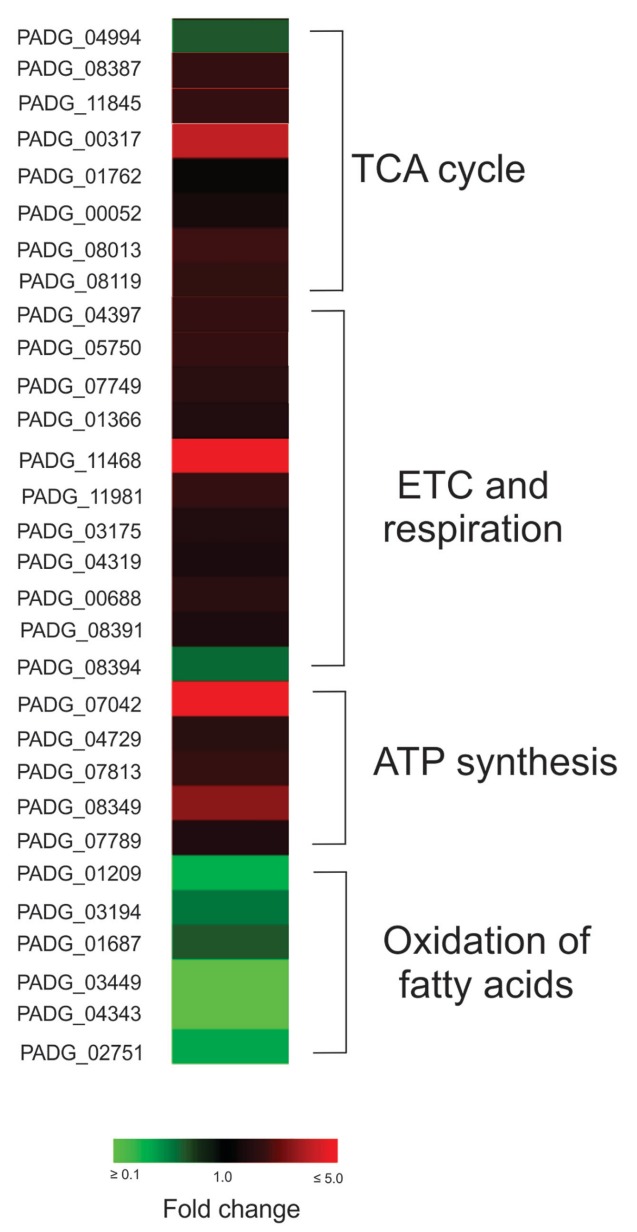

FIGURE 2 | Heat map showing up and down regulated cellular processes in $P$. brasiliensis infecting IFN $\gamma$ primed macrophages. Tricarboxylic acid cycle (TCA), electron transport chain (ETC), and ATP synthesis were predominantly up-regulated and oxidation of fatty acids is predominantly down-regulated in $P$. brasiliensis during incubation in IFN $\gamma$ primed macrophages. TCA, tricarboxylic cycle acid; ETC, electron transport chain; PADG_04994, citrate synthase subunit 1; PADG_08387, citrate synthase, mitochondrial; PADG_11845, aconitate hydratase, mitochondrial; PADG_00317, succinyl-CoA ligase subunit beta; PADG_01762, oxoglutarate dehydrogenase (succinyl-transferring), E1 component; PADG_00052, succinate dehydrogenase [ubiquinone] flavoprotein subunit, mitochondrial; PADG_08013, succinate dehydrogenase [ubiquinone] iron-sulfur subunit, mitochondrial; PADG_08119, fumarate hydratase, mitochondrial; PADG_04397, cytochrome c oxidase subunit 4, mitochondrial; PADG_05750, putative cytochrome c oxidase subunit; PADG_07749, NAD(P)H:quinone oxidoreductase, type IV; PADG_01366, NADH-ubiquinone oxidoreductase; PADG_11468, electron transfer flavoprotein beta-subunit; PADG_11981, V-type proton ATPase catalytic subunit A; PADG_03175, V-type proton ATPase subunit F; PADG_04319, V-type ATPase, G subunit; PADG_00688, F-type $\mathrm{H}+$-transporting ATPase subunit H; PADG_08391, plasma membrane ATPase; PADG_08394, cytochrome b-c1 complex subunit 2; PADG_07042, ATP synthase F1, delta subunit; PADG_04729, ATP synthase subunit D, mitochondrial; PADG_07813, ATP synthase F1, gamma subunit; PADG_08349, ATP synthase subunit beta, mitochondrial; PADG_07789, ATP synthase subunit delta, mitochondrial; PADG_01209, enoyl-CoA hydratase; PADG_03194, 3-ketoacyl-CoA thiolase B; PADG_01687, 3-ketoacyl-CoA thiolase; PADG_03449, isopentenyl-diphosphate delta-isomerase; PADG_04343, short chain dehydrogenase/reductase; PADG_02751, acetyl-CoA acetyltransferase. 
related to response to oxidative stress and virulence factors, as shown in Table 1 and Figure 3. SOD2, for example, had its expression more than twice higher in Pb18_NP compared to Pb18_P.

\section{P. brasiliensis, $P$ b18 Is Apparently Synthesizing More Cell Wall Components in Non-primed Macrophages}

We observed an increase of enzymes that participate in the synthesis of precursors of cell wall components as chitin, glycan, glycoproteins, and glycosylated compounds, mainly in Pb18_NP (Table 2; Figure 4). Enzymes as neutral alpha-glucosidase $\mathrm{AB}$, mannosil-oligosaccharide glucosidase, and alpha-mannosidase are involved in glycoprotein biosynthesis through the $N$-glycosylation process (Almeida et al., 2016). UDP-galactopyranose mutase, UTP-glucose-1phosphate uridylyltransferase, and UDP- $N$-acetylglucosamine pyrophosphorylase form UDP-sugars, substrates used in hundreds of glycosylation reactions (e.g., for protein and lipid glycosylation, synthesis of sucrose, and cell wall polysaccharides). UDP- $N$-acetylglucosamine pyrophosphorylase generates UDP$\mathrm{N}$-acetyl-D-glucosamine, which is used in the synthesis of chitin, for example (Decker et al., 2017). The up-regulation of the proteins involved in carbohydrate synthesis, interconversion, and utilization is shown in Figure 4. These data indicate that $P$. brasiliensis may be synthesizing components of the cell wall during infection, especially within non-primed macrophages.

Proteomic data were confirmed by fluorescence microscopy using aniline blue, ConA, and CFW as markers for glucans, carbohydrates residues in proteins (predominantly), and chitin, respectively (Figure 5). P. brasiliensis yeast cells recovered from non-primed macrophages presented higher fluorescence intensity of aniline blue, ConA, and CFW, suggesting higher content of glucans, carbohydrates residues from proteins, and chitin compared to fungal cells recovered from primed macrophages (Figure 5).

\section{P. brasiliensis, Pb18 Shows Higher Mitochondrial Activity in Non-primed Macrophage Infection}

Increase of proteins related to the electron transport chain and ATP synthesis complex were observed in yeast cells recovered from primed and non-primed macrophages. We used MitoTracker Green FM as a total mitochondrial dye (green) and the mitochondrial activity was evaluated by using rhodamine dye (red), which stains selectively according to mitochondrial membrane potential, as depicted in Figure 6. The fluorescence intensity of rhodamine was significantly increased in Pb18_NP compared to Pb18_P.

\section{DISCUSSION}

Despite the similarity in the adaptation pattern of $\mathrm{Pb} 18$ cells in primed and non-primed macrophages at $6 \mathrm{~h}$ post infection, our
TABLE 1 | Up-regulated proteins putatively related to cell rescue, defense, and virulence in Pb18_A and Pb18_NA.

\begin{tabular}{|c|c|c|c|}
\hline Accession number ${ }^{1}$ & Protein description & Pb18_P2 & Pb18_NP2 \\
\hline \multicolumn{4}{|l|}{ Defense and virulence } \\
\hline PADG_01479 & $\begin{array}{l}\text { Gamma- } \\
\text { glutamyltransferase }\end{array}$ & 1.76 & 2.46 \\
\hline PADG_06314 & Carboxypeptidase $Y$ & ND & 1.97 \\
\hline PADG_07460 & $\begin{array}{l}\text { Vacuolar } \\
\text { aminopeptidase }\end{array}$ & 1.53 & 1.82 \\
\hline PADG_07422 & Serine proteinase & 1.8 & 2.17 \\
\hline PADG_07674 & Carbonic anhydrase & ND & 1.55 \\
\hline \multicolumn{4}{|l|}{ Stress response } \\
\hline PADG_00778 & Hsp70 & ND & 1.43 \\
\hline PADG_02030 & $\begin{array}{l}\text { Hsp90 co-chaperone } \\
\text { Cdc37 }\end{array}$ & $2 . .22$ & 2.71 \\
\hline PADG_02785 & $\begin{array}{l}\text { Heat shock protein } \\
\text { Hsp88 }\end{array}$ & 1.5 & 1.48 \\
\hline PADG_03963 & $\begin{array}{l}30 \mathrm{kDa} \text { heat shock } \\
\text { protein }\end{array}$ & 1.84 & 2.05 \\
\hline PADG_04379 & $\begin{array}{l}\text { Heat shock protein } \\
\text { STI1 }\end{array}$ & 1.99 & 2.09 \\
\hline \multicolumn{4}{|l|}{ Detoxification } \\
\hline PADG_01551 & Thioredoxin reductase & 1.56 & 1.84 \\
\hline PADG_01954 & $\begin{array}{l}\text { Superoxide dismutase } \\
2 \mathrm{Fe}-\mathrm{Mn} \text {, mitochondrial }\end{array}$ & 1.99 & 4.72 \\
\hline PADG_07418 & $\begin{array}{l}\text { Superoxide dismutase } \\
1 \mathrm{Cu}-\mathrm{Zn} \text {, cytosolic }\end{array}$ & 1.99 & 2.78 \\
\hline
\end{tabular}

${ }^{1}$ Accession number obtained in the Paracoccidioides database available at http://www.broadinstitute.org/annotation/genome/paracoccidioides_brasiliensis/ MultiHome.html. ${ }^{2}$ Ratio values were obtained by dividing the values of protein abundance (in fmol) from Pb18 during infection of activated and non-activated macrophages, by the abundance in control. Proteins with a minimum fold change of $40 \%$ were considered regulated. ND, non-detected proteins.

results could suggest that metabolic ability to regulate pathways and proteins important to ensure fungal survival is diminished in the fungus after interaction with primed macrophages. Many adaptation strategies have been described as essential for the viability of fungi under nutrient deprivation conditions, such as up regulation of gluconeogenesis, fatty acids degradation, glyoxylate cycle (Seider et al., 2014).

The intracellular environment imposes numerous difficulties to pathogens, such as the action of hydrolytic enzymes, nutrient deprivation, and presence of reactive species of oxygen and nitrogen (Haass et al., 2007). To establish the infection, pathogens require a metabolic flexibility to assimilate the available nutrients and a powerful antioxidant system that allows them to survive intracellularly (Seider et al., 2014; Kasper et al., 2015; Camacho and Nino-Vega, 2017). The cells of the innate immune system, mainly macrophages and neutrophils, are the primary line of defense against Paracoccidioides infection (Franco, 1987; Calich et al., 2008; Mendes-Giannini et al., 2008). However, microscopic findings show that Paracoccidioides is able to survive and multiply inside phagocytes, although this ability is inhibited by the activation of these cells with IFN- $\gamma$ (Brummer et al., 1988; Rodrigues et al., 2007). Those findings were confirmed in our work, where we determined a time-course survival of $P$. brasiliensis during interaction with non-primed 


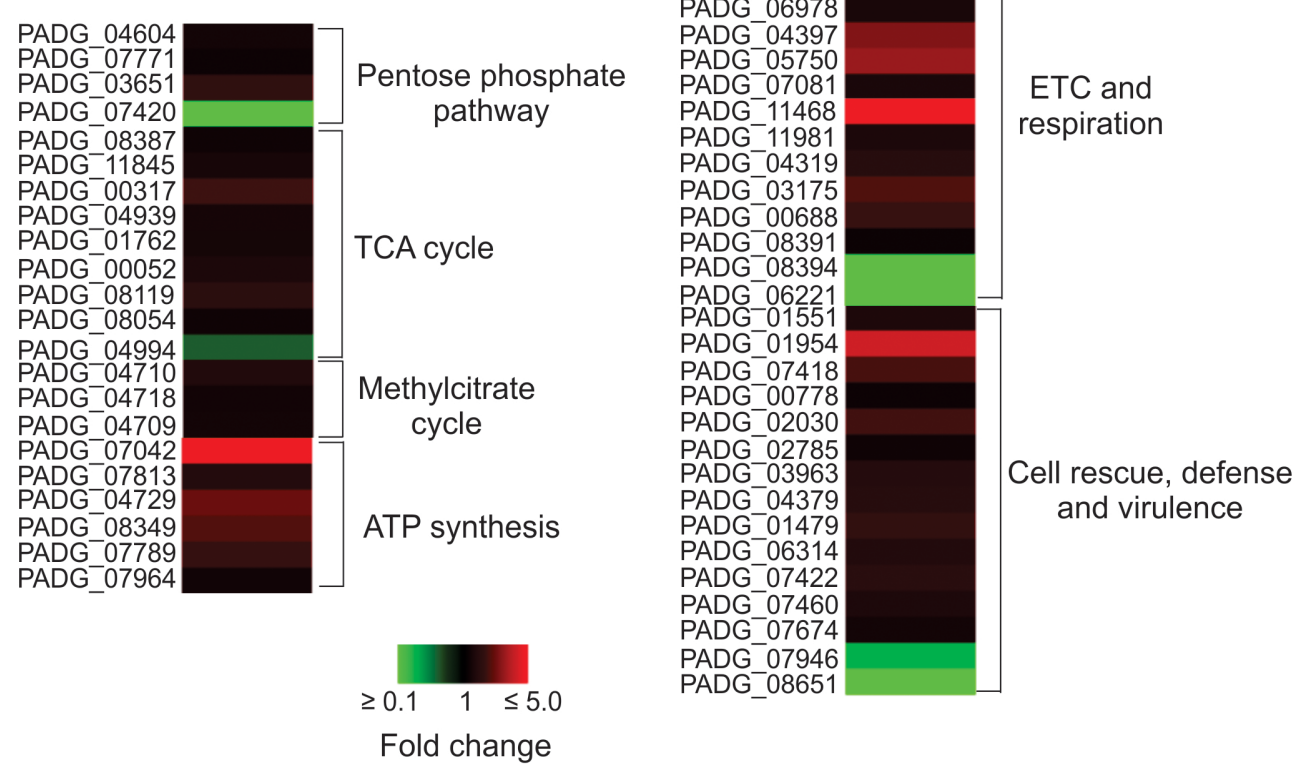

FIGURE 3 | Heat map showing the cellular processes predominantly up regulated in non-primed macrophages. The most up-regulated processes are ETC and ATP synthesis. TCA, tricarboxylic cicle acid; ETC, electron transport chain; PADG_04604, transketolase; PADG_07771, 6-phosphogluconolactonase; PADG_03651, 6-phosphogluconate dehydrogenase, decarboxylating 1; PADG_07420, transaldolase; PADG_08387, citrate synthase mitochondrial; PADG_11845, aconitate hydratase mitochondrial; PADG_00317, succinyl-CoA ligase subunit beta; PADG_04939, succinyl-CoA, 3-ketoacid-coenzyme A transferase; PADG_01762, oxoglutarate dehydrogenase; PADG_00052, succinate dehydrogenase [ubiquinone] flavoprotein, mitochondrial; PADG_08119, fumarate hydratase, mitochondrial; PADG_08054, malate dehydrogenase, NAD-dependent; PADG_04994, ATP-citrate-lyase; PADG_04710, 2-methylcitrate synthase, mitochondrial; PADG_04718, 2-methylcitrate dehydratase; PADG_04709, methyl-isocitrate lyase; PADG_07042, ATP synthase F1, delta subunit; PADG_07813, ATP synthase F1, gamma subunit; PADG_04729, ATP synthase subunit D, mitochondrial; PADG_08349, ATP synthase subunit beta, mitochondrial; PADG_07789, ATP synthase subunit delta, mitochondrial; PADG_07964, vacuolar ATP synthase subunit E; PADG_07749, NAD(P)H:quinone oxidoreductase, type IV; PADG_01366, NADH-ubiquinone oxidoreductase 1 alpha subcomplex subunit 5; PADG_02745, NADH-ubiquinone oxidoreductase Fe-S protein 6; PADG_06978, cytochrome C; PADG_04397, cytochrome c oxidase subunit 4, mitochondrial; PADG_05750, cytochrome c oxidase subunit; PADG_07081, electron transfer flavoprotein subunit alpha; PADG_11468, electron transfer flavoprotein beta-subunit; PADG_11981, V-type proton ATPase catalytic subunit A; PADG_04319, V-type ATPase, G subunit; PADG_03175, V-type proton ATPase subunit F; PADG_00688, F-type H+-transporting ATPase subunit H; PADG_08391, plasma membrane ATPase; PADG_08394, cytochrome b-c1 complex subunit 2; PADG_06221, formate dehydrogenase; PADG_01551, thioredoxin reductase; PADG_01954, superoxide dismutase 2 Fe-Mn; PADG_07418, superoxide dismutase 1 Cu-Zn; PADG_00778, Hsp70; PADG_02030, Hsp90 co-chaperone Cdc37; PADG_02785, heat shock protein Hsp88; PADG_03963, 30 kDa heat shock protein; PADG_04379, heat shock protein STI1; PADG_01479, $\gamma$-glutamyltransferase; PADG_06314, carboxypeptidase Y; PADG_07422, serine proteinase; PADG_07460, vacuolar aminopeptidase; PADG_07674, carbonic anhydrase; PADG_07946, peroxisomal matrix protein; PADG_08651, peroxisomal hydratase-dehydrogenase-epimerase.

macrophages. The cells primed with INF- $\gamma$ showed increase in the adherence/internalization index in the first $6 \mathrm{~h}$ of interaction, while the adherence/internalization of the fungus in non-primed macrophages was affected only after $9 \mathrm{~h}$ of infection (Figure 1A). This difference in the fungicidal potential between primed and non-primed phagocytes was observed in infection assays with several Paracoccidioides isolates. The addition of INF- $\gamma$ did not increase the phagocytosis index, but it confers microbicidal activity to the macrophages in a dose-dependent manner, as described (Brummer et al., 1988, 1989).

Previous proteomic and transcriptomic studies revealed that pathogenic bacteria and fungi reprogram their metabolism, regulating negatively the glycolytic pathway and activating alternative routes of carbon consumption, as gluconeogenesis, amino acid degradation, fatty acids oxidation, glyoxylate cycle, and ethanol production, during macrophage infection (Sprenger et al., 2017). Our analysis revealed that P. brasiliensis was able to modify its metabolism in both conditions, intracellular environment of primed and non-primed macrophages with INF- $\gamma$. However, $P$. brasiliensis stress response is most evident during interaction with the non-primed macrophages with IFN- $\gamma$, suggesting fungal cells ability to respond and survive during interaction with non-primed macrophages is increased compared to primed-macrophages (Supplementary Tables 2, 3). The fungus adaptation during interaction with non-primed macrophages is also more evident when we analyzed the pentosephosphate pathway, methylcitrate cycle, and synthesis of cell wall precursors (Figures 3, 4; Supplementary Table 3). The activation of those pathways in $P$. brasiliensis after interaction with non-primed macrophages may favor the fungus survival in the hostile environment in the macrophages. The pentosephosphate pathway also contributes to the defense against oxidative stress since it provides NADPH. The methylcitrate 
TABLE 2 | Up-regulated proteins putatively related to the homeostasis of cell wall componets in Pb18_A and Pb18_NA.

\begin{tabular}{lllc}
\hline Accession number & Protein description & Pb18_P & Pb18_NP \\
\hline $\begin{array}{l}\text { N-glycosylation } \\
\text { PADG_07523 }\end{array}$ & $\begin{array}{l}\text { Neutral alpha-glucosidase } \\
\text { AB }\end{array}$ & 1.91 & 2.54 \\
PADG_04761 & $\begin{array}{l}\text { Mannosyl-oligosaccharide } \\
\text { glucosidase }\end{array}$ & 1.84 & 2.25 \\
PADG_04148 & $\begin{array}{l}\text { Alpha-mannosidase } \\
\text { UDP-sugars }\end{array}$ & ND & 1.7 \\
PADG_00912 & $\begin{array}{l}\text { UDP-galactopyranose } \\
\text { mutase }\end{array}$ & ND & 2.46 \\
PADG_04374 & $\begin{array}{l}\text { UTP-glucose-1-phosphate } \\
\text { uridylyltransferase } \\
\text { UDP-N-acetylglucosamine } \\
\text { pyrophosphorylase }\end{array}$ & $*$ & $*$ \\
PADG_04312 & ND & 1.4 \\
Mannan & $\begin{array}{l}\text { Phosphomannomutase } \\
\text { PADG_03943 }\end{array}$ & $*$ & $*$
\end{tabular}

${ }^{1}$ Accession number obtained in the Paracoccidioides database available at http://www.broadinstitute.org/annotation/genome/paracoccidioides_brasiliensis/ MultiHome.html. ${ }^{2}$ Ratio values were obtained by dividing the values of protein abundance (in fmol) from Pb18 during infection of activated and non-activated macrophages, by the abundance in control. Proteins with a minimum fold change of $40 \%$ were considered regulated. *Proteins detected in P. brasiliensis Pb18 only during respective macrophage infection. ND, non-detected proteins.

synthase is essential for the degradation of toxic compounds as propionyl-CoA, and is necessary for the pathogen A. fumigattus to establish infection in murines (Ibrahim et al., 2008). The up-regulation of those pathways was also observed in $P$. brasiliensis during $6 \mathrm{~h}$ of murine lung infection and after $24 \mathrm{~h}$ of infection in J774 macrophages (ParenteRocha et al., 2015; Pigosso et al., 2017). Those metabolic peculiarities indicate that the intracellular environment of primed macrophages prevents the fungus from rapidly activating strategic pathways of metabolic adaptation, as it does in nonprimed macrophages.

It was possible to observe the accumulation of glycolytic enzymes that can generate precursors of Paracoccidioides cell wall components, in $P$. brasilensis recovered of non-primed macrophages (Table 2). Proteomic data were confirmed by fluorescence microscopy, since higher amounts of glucans, glycosylated proteins, and chitin were observed in the cell wall of yeasts recovered from non-primed macrophages (Figure 5).

Our data corroborated studies previously conducted (Brummer et al., 1989) in which the morphology of $P$. brasiliensis presented differences after internalization by primed and nonprimed peritoneal macrophages. During infection of primed macrophages, it was observed deterioration of the fungus cell wall until complete digestion and elimination, while in non-primed macrophages the $P$. brasiliensis cell wall remained intact. C. neoformans also depicted induction in the expression of genes encoding enzymes involved in polysaccharide synthesis, during infection in primed macrophages infection, which may be associated with the formation of cell wall or capsule components (Fan et al., 2005). Our results suggest that the cell

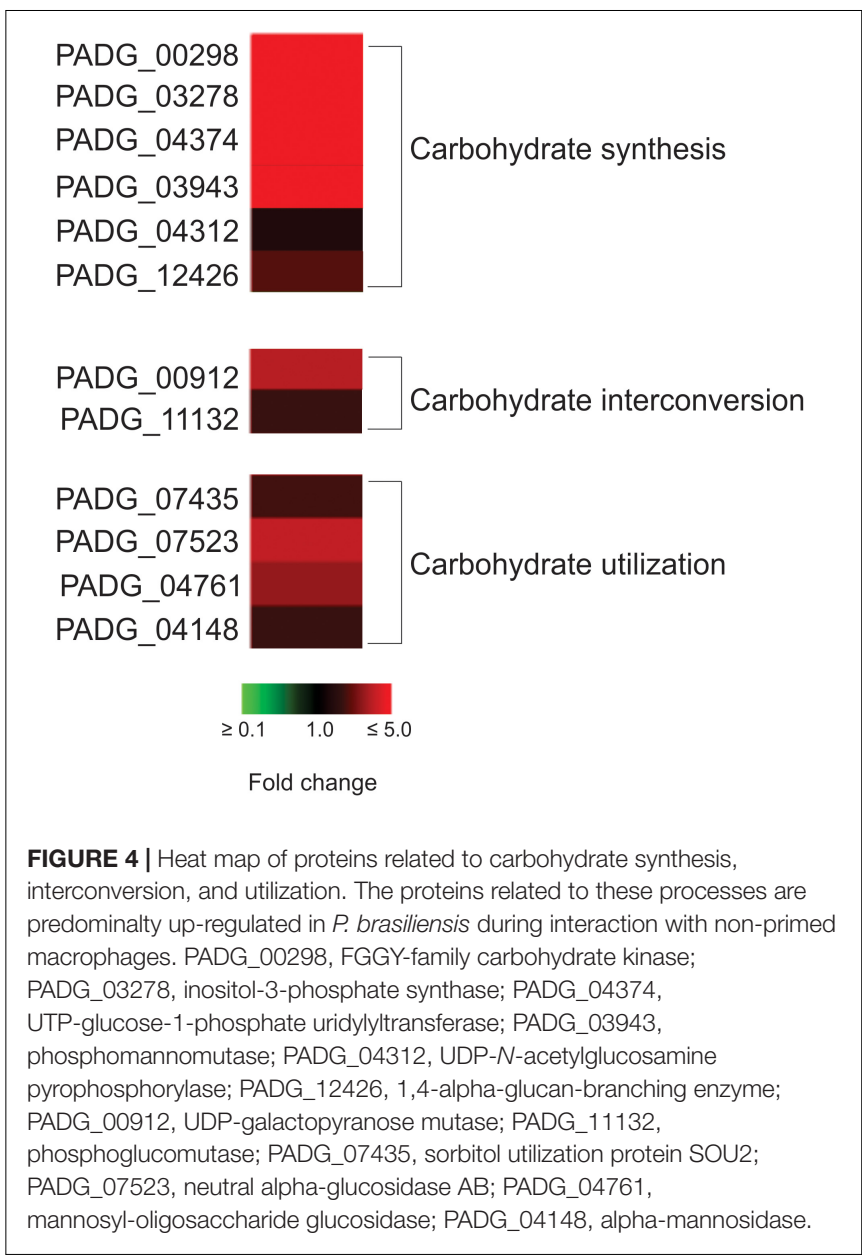

wall maintenance and remodeling probably occurs because non-primed macrophage allows the survival and multiplication of the fungus.

A higher abundance of proteins related to electron carrier chain and ATP synthesis was detected in $P$. brasiliensis derived from non-primed macrophages (Figure 2 and Table 3 ). We evaluated the mitochondrial activity of $P$. brasiliensis by labeling yeast cells with mitotracker and rhodamine. The latter, dyes mitochondria according to membrane potential. The fluorescence intensity of rhodamine was higher in yeast cells during infection of non-primed macrophages, which indicates an increased mitochondrial activity (Figure 6). Among the functions performed by mitochondria, we can highlight the supply of cellular energy, cross-talk between pro-survival and pro-death pathways, and also role in the response to metabolic stress (Nunnari and Suomalainen, 2012). A study with Aspergillus nidulans demonstrated that the mutant strain of a gene related to mitochondrial function and cellular respiration presented a decrease in the mass and function of mitochondria and of oxidative phosphorylation process, which influenced glucose uptake. This deletion also led to an increase in endogenous ROS levels, which is toxic to the cell (Krohn et al., 2014). 


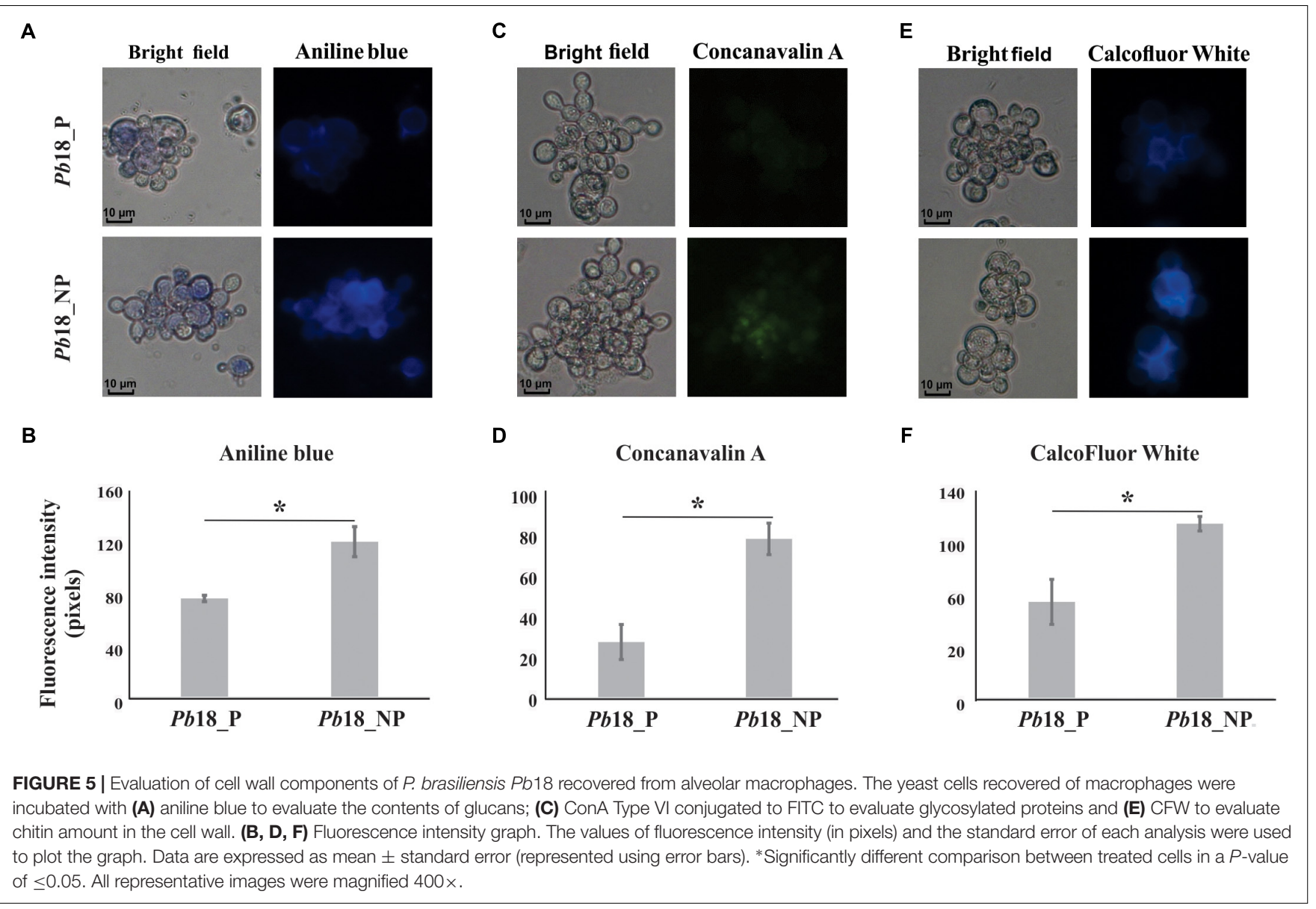

Interestingly, gluconeogenesis has been described as a crucial strategy during the first steps of $C$. neoformans infection, whereas glycolysis has importance later, being fundamental for the permanence of the pathogen in the host (Price et al., 2011). Our proteomic analyzes showed that, in primed and non-primed macrophage infection, $\mathrm{Pb} 18$ cells did not exhibit up-regulation of gluconeogenesis (Supplementary Tables 2, 3). This data are also observed in P. brasiliensis after 6 h of lung murine infection; the authors suggest the occurrence of glucose reserve, since the fungus was grown in a nutrient rich medium prior to infection (Pigosso et al., 2017). In this sense, activation of gluconeogenesis has been observed in $\mathrm{Pb} 18$ after a longer period of infection in macrophages (Parente-Rocha et al., 2015).

The fungus also increased the expression of proteins involved in cell rescue, defense, and virulence in both conditions (Table 1). Autophagic proteins as serine proteinase (PADG_07422), vacuolar aminopeptidase (PADG_07460), carboxypeptidase Y (PADG_06314) were up-regulated. These enzymes have been described as important virulence factors that promote the recycling of cytoplasmic components in pathogen starvation mode. Autophagic processes have been described in S. cerevisiae and Candida glabrata as a way of survival in the host and during nitrogen starvation and depletion of nutrients (Inoue and Klionsky, 2010; Roetzer et al., 2010). Serine proteinase has recently been described in $P$. brasiliensis as a virulence factor that favors survival upon nitrogen deprivation, as well as tissue invasion, since it is secreted in large amounts in the host during lung murine infection (Parente et al., 2010; Pigosso et al., 2017).

Here, it was also observed, an increased expression of heat shock proteins and proteins involved in detoxification and stress response, as TrxR (PADG_01551) and SOD (PADG_01954 and PADG_07418) in P. brasiliensis recovered of primed and non-primed macrophages, although the higher expression was observed in the last condition (Table 1). TrxR, which works in conjunction with thioredoxin, is induced in Paracoccidioides during oxidative stress and infection assays (Table 1). The TrxR, which works in conjunction with thioredoxin, is induced in Paracoccidioides during oxidative stress and infection assays (Grossklaus et al., 2013; Pigosso et al., 2017). TrxR is a molecule of antioxidant resistance, since it binds to NADPH and reduces thioredoxin, forming thioredoxin disulfide and $\mathrm{NADP}^{+}$; the final reaction contributes to the removal of superoxide radicals (Yoshida et al., 2003; Missall and Lodge, 2005). Some fungi such as members of Candida species increase the expression of the thioredoxin system during oxidative and nitrosative stresses (Brown et al., 2009). In C. neoformans, the action of this enzyme also gives high virulence to the fungus. This enzyme has called attention as a possible target of antifungal drugs against 


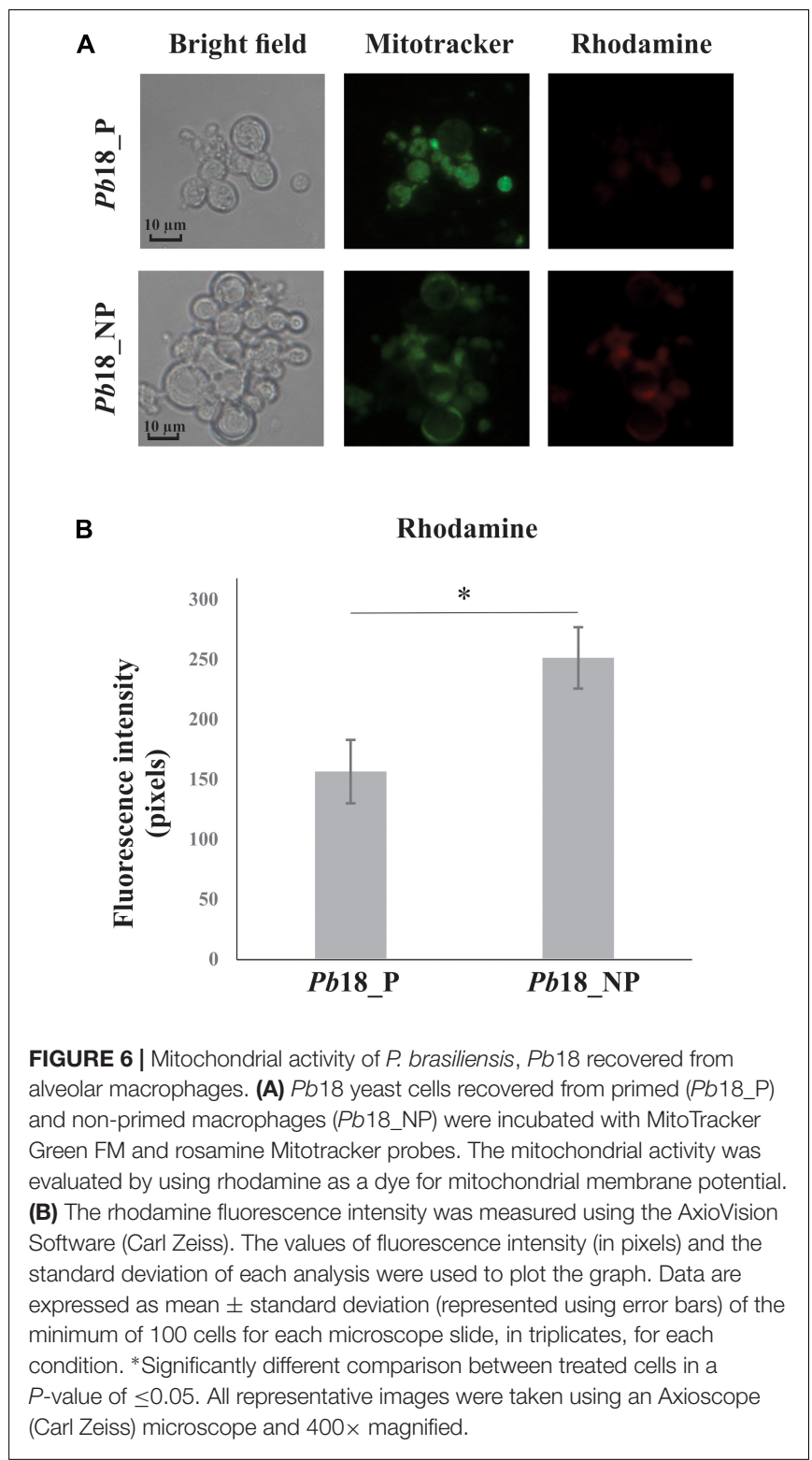

Paracoccidioides infection (Missall and Lodge, 2005; Abadio et al., 2015).

In synthesis, all the data indicate that the $P$. brasiliensis adapts rapidly within not primed macrophages, where it can multiply and probably spread through the tissues of the host. The data corroborate with clinical data, that report patients with acute or chronic PCM presenting low production of phagocyte activating cytokines, such as INF- $\gamma$, IL-12, and TNF$\alpha$ (Benard et al., 2001). These cytokines play an important role in the microbicidal activity of macrophages, recruitment of defense cells to the site of infection and formation of efficient granulomas to contain the dissemination of Paracoccidioides (Nishikaku et al., 2011). This comparative proteomic study contributes to the understanding of factors that can lead to the inhibition or evolution of PCM as well as its pathogenesis.
TABLE 3 | Up-regulated proteins related with mitochondrial activity in Pb18_A and Pb18_NA.

\begin{tabular}{|c|c|c|c|}
\hline Accession number ${ }^{1}$ & Protein description & Pb18_P2 & Pb18_NP2 \\
\hline \multicolumn{4}{|l|}{ ATP synthesis } \\
\hline PADG_04729 & $\begin{array}{l}\text { ATP synthase subunit } \\
\text { D, mitochondrial }\end{array}$ & 2.09 & 3.24 \\
\hline PADG_07042 & $\begin{array}{l}\text { ATP synthase F1, delta } \\
\text { subunit }\end{array}$ & * & * \\
\hline PADG_07813 & $\begin{array}{l}\text { ATP synthase F1, } \\
\text { gamma subunit }\end{array}$ & 2.38 & 2.02 \\
\hline PADG_08349 & $\begin{array}{l}\text { ATP synthase subunit } \\
\text { beta, mitochondrial }\end{array}$ & 3.38 & 2.92 \\
\hline PADG_07789 & $\begin{array}{l}\text { ATP synthase subunit } \\
\text { delta, mitochondrial }\end{array}$ & 1.84 & 2.53 \\
\hline PADG_07964 & $\begin{array}{l}\text { Vacuolar ATP synthase } \\
\text { subunit E }\end{array}$ & ND & 1.52 \\
\hline
\end{tabular}

Electron transport and membrane-associated energy conservation

\begin{tabular}{|c|c|c|c|}
\hline PADG_11981 & $\begin{array}{l}\text { V-type proton ATPase } \\
\text { catalytic subunit A }\end{array}$ & 2.36 & 1.81 \\
\hline PADG_04319 & $\begin{array}{l}\text { V-type ATPase, G } \\
\text { subunit }\end{array}$ & 1.75 & 2.08 \\
\hline PADG_00688 & $\begin{array}{l}\mathrm{F} \text {-type } \mathrm{H} \text {--transporting } \\
\text { ATPase subunit } \mathrm{H}\end{array}$ & 2.11 & 2.56 \\
\hline PADG_03175 & $\begin{array}{l}\text { V-type proton ATPase } \\
\text { subunit F }\end{array}$ & 1.87 & 2.88 \\
\hline PADG_08391 & $\begin{array}{l}\text { Plasma membrane } \\
\text { ATPase }\end{array}$ & ND & 1.41 \\
\hline PADG_07081 & $\begin{array}{l}\text { Electron transfer } \\
\text { flavoprotein subunit } \\
\text { alpha }\end{array}$ & ND & 1.74 \\
\hline PADG_11468 & $\begin{array}{l}\text { Electron transfer } \\
\text { flavoprotein } \\
\text { beta-subunit }\end{array}$ & * & $*$ \\
\hline PADG_06978 & Cytochrome C & ND & 1.68 \\
\hline PADG_04397 & $\begin{array}{l}\text { Cytochrome c oxidase } \\
\text { subunit } 4 \text {, } \\
\text { mitochondrial }\end{array}$ & 2.88 & 3.55 \\
\hline PADG_05750 & $\begin{array}{l}\text { Putative cytochrome c } \\
\text { oxidase subunit Via }\end{array}$ & 2.5 & 3.89 \\
\hline PADG_02745 & $\begin{array}{l}\text { NADH-ubiquinone } \\
\text { oxidoreductase } \mathrm{Fe}-\mathrm{S} \\
\text { protein } 6\end{array}$ & ND & * \\
\hline PADG_07749 & $\begin{array}{l}\mathrm{NAD}(\mathrm{P}) \mathrm{H} \text { :quinone } \\
\text { oxidoreductase, type IV }\end{array}$ & 1.59 & 2.34 \\
\hline PADG_01366 & $\begin{array}{l}\text { NADH-ubiquinone } \\
\text { oxidoreductase } 1 \text { alpha } \\
\text { subcomplex subunit } 5\end{array}$ & 1.82 & 2.21 \\
\hline
\end{tabular}

${ }^{1}$ Accession number obtained in the Paracoccidioides database available at http://www.broadinstitute.org/annotation/genome/paracoccidioides_brasiliensis/ MultiHome.html. ${ }^{2}$ Ratio values were obtained by dividing the values of protein abundance (in fmol) from Pb18 during infection of activated and non-activated macrophages, by the abundance in control. Proteins with a minimum fold change of $40 \%$ were considered regulated. *Proteins detected in P. brasiliensis Pb18 only during respective macrophage infection. ND, non-detected proteins.

\section{CONCLUDING REMARKS}

Comparative proteomic analysis of $P$. brasiliensis during phagocyte infection revealed metabolic peculiarities that favor the survival of $P$. brasiliensis in the intracellular environment of non-primed macrophages. In both conditions, primed and 
non-primed macrophages, the fungus increased the expression of enzymes related to amino acid degradation, TCA and glyoxylate cycles, antioxidant enzymes, and virulence factors. However, activation of the pentose-phosphate pathway, methylcytrate cycle, synthesis of cell wall precursors, and intense mitochondrial activity was observed mainly in yeast cells recovered from non-primed macrophages. These pathways may favor the viability of the fungus compared to yeasts internalized by primed phagocytes. Considering the obtained data, we could suggest that, compared to primed macrophages, non-primed macrophages allow a more permissive environment to $P$. brasiliensis to adapt to the host milieu.

\section{AUTHOR CONTRIBUTIONS}

CS conceived and finalized the manuscript. EC and DA performed the experiments. LB carried out proteomic data. JP-R contributed in the experiments design and performed the heat maps. EC, DA, LB, JP-R, CB, MO, and CS designed the study,

\section{REFERENCES}

Abadio, A. K., Kioshima, E. S., Leroux, V., Martins, N. F., Maigret, B., and Felipe, M. S. (2015). Identification of new antifungal compounds targeting thioredoxin reductase of Paracoccidioides genus. PLoS One 10:e0142926. doi: 10.1371/journal.pone.0142926

Almeida, F., Antonieto, A. C., Pessoni, A. M., Monteiro, V. N., AlegreMaller, A. C., Pigosso, L. L., et al. (2016). Influence of N-glycans on expression of cell wall remodeling related genes in Paracoccidioides brasiliensis yeast cells. Curr. Genom. 17, 112-118. doi: 10.2174/1389202917666151116 212705

Askew, C., Sellam, A., Epp, E., Hogues, H., Mullick, A., Nantel, A., et al. (2009). Transcriptional regulation of carbohydrate metabolism in the human pathogen Candida albicans. PLoS Pathog. 5:e1000612. doi: 10.1371/journal.ppat.1000612

Baeza, L. C., da Mata, F. R., Pigosso, L. L., Pereira, M., de Souza, G., Coelho, A. S. G., et al. (2017). Differential metabolism of a two-carbon substrate by members of the Paracoccidioides genus. Front. Microbiol. 8:2308. doi: 10.3389/fmicb.2017. 02308

Benard, G., Romano, C. C., Cacere, C. R., Juvenale, M., Mendes-Giannini, M. J., and Duarte, A. J. (2001). Imbalance of IL-2, IFN- $\gamma$ and IL10 secretion in the immunosuppression associated with human paracoccidioidomycosis. Cytokine 13, 248-252. doi: 10.1006/cyto.2000 .0824

Bernard, M., and Latge, J. P. (2001). Aspergillus fumigatus cell wall: composition and biosynthesis. Med. Mycol. 39(Suppl. 1), 9-17. doi: 10.1080/mmy.39.1.9.17

Brown, A. J., Haynes, K., and Quinn, J. (2009). Nitrosative and oxidative stress responses in fungal pathogenicity. Curr. Opin. Microbiol. 12, 384-391. doi: 10.1016/j.mib.2009.06.007

Brummer, E., Hanson, L. H., Restrepo, A., and Stevens, D. A. (1988). In vivo and in vitro activation of pulmonary macrophages by IFN- $\gamma$ for enhanced killing of Paracoccidioides brasiliensis or Blastomyces dermatitidis. J. Immunol. 140, 2786-2789.

Brummer, E., Hanson, L. H., Restrepo, A., and Stevens, D. A. (1989). Intracellular multiplication of Paracoccidioides brasiliensis in macrophages: killing and restriction of multiplication by activated macrophages. Infect. Immun. 57, 2289-2294.

Calich, V. L., da Costa, T. A., Felonato, M., Arruda, C., Bernardino, S., Loures, F. V., et al. (2008). Innate immunity to Paracoccidioides brasiliensis infection. Mycopathologia 165, 223-236. doi: 10.1007/s11046-007-9048-1 discussed, analyzed, and interpreted the data and wrote the manuscript.

\section{FUNDING}

This work at Universidade Federal de Goiás was supported by grants from Conselho Nacional de Desenvolvimento Científico e Tecnológico (CNPq), Fundação de Amparo à Pesquisa do Estado de Goiás (FAPEG), Instituto Nacional de Ciência e Tecnologia da Interação Patógeno Hospedeiro (IPH), and Programa Nacional de Pós-Doutorado - Coordenação de Aperfeiçoamento de Pessoal de Nível Superior (PNPD-CAPES). This work is part of the INCT program of Strategies of HPI and is part of the EGAC Doctoral Thesis.

\section{SUPPLEMENTARY MATERIAL}

The Supplementary Material for this article can be found online at: https://www.frontiersin.org/articles/10.3389/fmicb. 2019.00096/full\#supplementary-material

Camacho, E., and Nino-Vega, G. A. (2017). Paracoccidioides Spp: virulence factors and immune-evasion strategies. Med. Inflamm. 2017:5313691. doi: 10.1155/ $2017 / 5313691$

Carrero, L. L., Nino-Vega, G., Teixeira, M. M., Carvalho, M. J., Soares, C. M. A., Pereira, M., et al. (2008). New Paracoccidioides brasiliensis isolate reveals unexpected genomic variability in this human pathogen. Fungal. Genet. Biol. 45, 605-612. doi: 10.1016/j.fgb.2008.02.002

de Curcio, J. S., Silva, M. G., Silva-Bailão, M. G., Báo, S. N., Casaletti, L., Bailão, A. M., et al. (2017). Identification of membrane proteome of Paracoccidioides lutzii and its regulation by zinc. Fut. Sci. OA 3:FSO232. doi: 10.4155/fsoa-20170044

Decker, D., Oberg, C., and Kleczkowski, L. A. (2017). Identification and characterization of inhibitors of UDP-glucose and UDP-sugar pyrophosphorylases for in vivo studies. Plant J. 90, 1093-1107. doi: $10.1111 /$ tpj.13531

Erwig, L. P., and Gow, N. A. (2016). Interactions of fungal pathogens with phagocytes. Nat. Rev. Microbiol. 14, 163-176. doi: 10.1038/nrmicro.2015.21

Fan, W., Kraus, P. R., Boily, M. J., and Heitman, J. (2005). Cryptococcus neoformans gene expression during murine macrophage infection. Eukaryot Cell 4, 14201433. doi: 10.1128/EC.4.8.1420-1433.2005

Fang, F. C. (2004). Antimicrobial reactive oxygen and nitrogen species: concepts and controversies. Nat. Rev. Microbiol. 2, 820-832. doi: 10.1038/nrmicro 1004

Fava-Netto, C. (1955). Estudos quantitativos sobre a fixação de complemento na blastomicose sul-americana, com antígeno polissacarídico. Arq. Cir. Clin. Exp. $18,197-254$.

Ferrari, C. K., Souto, P. C., Franca, E. L., and Honorio-Franca, A. C. (2011). Oxidative and nitrosative stress on phagocytes' function: from effective defense to immunity evasion mechanisms. Arch. Immunol. Ther. Exp. 59, 441-448. doi: 10.1007/s00005-011-0144-z

Fortes, M. R., Miot, H. A., Kurokawa, C. S., Marques, M. E., and Marques, S. A. (2011). Immunology of paracoccidioidomycosis. An. Bras. Dermatol. 86, 516-524. doi: 10.1590/S0365-05962011000300014

Franco, M. (1987). Host-parasite relationships in paracoccidioidomycosis. J. Med. Vet. Mycol. 25, 5-18. doi: 10.1080/02681218780000021

Geromanos, S. J., Vissers, J. P., Silva, J. C., Dorschel, C. A., Li, G. Z., Gorenstein, M. V., et al. (2009). The detection, correlation, and comparison of peptide precursor and product ions from data independent LC-MS with data dependant LC-MS/MS. Proteomics 9, 1683-1695. doi: 10.1002/pmic.200800562 
Gori, S., and Scasso, A. (1994). Cytologic and differential diagnosis of rhinosporidiosis. Acta Cytol. 38, 361-366.

Grossklaus, D. A., Bailao, A. M., Vieira Rezende, T. C., Borges, C. L., de Oliveira, M. A., Parente, J. A., et al. (2013). Response to oxidative stress in Paracoccidioides yeast cells as determined by proteomic analysis. Microbes Infect. 15, 347-364. doi: 10.1016/j.micinf.2012.12.002

Haas, A. (2007). The phagosome: compartment with a license to kill. Traffic 8, 311-330. doi: 10.1111/j.1600-0854.2006.00531.x

Haass, F. A., Jonikas, M., Walter, P., Weissman, J. S., Jan, Y. N., Jan, L. Y., et al. (2007). Identification of yeast proteins necessary for cell-surface function of a potassium channel. Proc. Natl. Acad. Sci. U.S.A. 104, 18079-18084. doi: 10.1073/ pnas.0708765104

Hanna, S. A., Monteiro da Silva, J. L., and Giannini, M. J. (2000). Adherence and intracellular parasitism of Paracoccidioides brasiliensis in vero cells. Microbes Infect. 2, 877-884. doi: 10.1016/S1286-4579(00)00390-7

Ibrahim, A. S., Spellberg, B., and Edwards, J. Jr. (2008). Iron acquisition: a novel perspective on mucormycosis pathogenesis and treatment. Curr. Opin. Infect. Dis. 21, 620-625. doi: 10.1097/QCO.0b013e3283165fd 1

Inoue, Y., and Klionsky, D. J. (2010). Regulation of macroautophagy in Saccharomyces cerevisiae. Semin. Cell Dev. Biol. 21, 664-670. doi: 10.1016/j. semcdb.2010.03.009

Kasper, L., Seider, K., and Hube, B. (2015). Intracellular survival of Candida glabrata in macrophages: immune evasion and persistence. FEMS Yeast Res. 15:fov042. doi: 10.1093/femsyr/fov042

Krohn, N. G., Brown, N. A., Colabardini, A. C., Reis, T., Savoldi, M., Dinamarco, T. M., et al. (2014). The Aspergillus nidulans ATM kinase regulates mitochondrial function, glucose uptake and the carbon starvation response. G3 4, 49-62. doi: 10.1534/g3.113.008607

Lange, C., DeMeo, D., Silverman, E. K., Weiss, S. T., and Laird, N. M. (2004). PBAT: tools for family-based association studies. Am. J. Hum. Genet. 74, 367-369. doi: $10.1086 / 381563$

Lima, P. S., Casaletti, L., Bailao, A. M., Vasconcelos, A. T., Fernandes, G. R., and Soares, C. M. A. (2014). Transcriptional and proteomic responses to carbon starvation in Paracoccidioides. PLoS Negl. Trop. Dis. 8:e2855. doi: 10.1371/ journal.pntd.0002855

Lorenz, M. C., and Fink, G. R. (2002). Life and death in a macrophage: role of the glyoxylate cycle in virulence. Eukaryot Cell 1, 657-662. doi: 10.1128/EC.1.5.657662.2002

Martinez, R. (2017). New trends in Paracoccidioidomycosis epidemiology. J. Fungi 3:1. doi: 10.3390/jof3010001

Matute, D. R., Sepulveda, V. E., Quesada, L. M., Goldman, G. H., Taylor, J. W., Restrepo, A., et al. (2006). Microsatellite analysis of three phylogenetic species of Paracoccidioides brasiliensis. J. Clin. Microbiol. 44, 2153-2157. doi: 10.1128/ JCM.02540-05

McEwen, J. G., Restrepo, B. I., Salazar, M. E., and Restrepo, A. (1987). Nuclear staining of Paracoccidioides brasiliensis conidia. J. Med. Vet. Mycol. 25, 343-345. doi: $10.1080 / 02681218780000411$

Mendes-Giannini, M. J., Hanna, S. A., da Silva, J. L., Andreotti, P. F., Vincenzi, L. R., Benard, G., et al. (2004). Invasion of epithelial mammalian cells by Paracoccidioides brasiliensis leads to cytoskeletal rearrangement and apoptosis of the host cell. Microbes Infect. 6, 882-891. doi: 10.1016/j.micinf.2004.05.005

Mendes-Giannini, M. J., Monteiro da Silva, J. L., de Fatima da Silva, J., Donofrio, F. C., Miranda, E. T., Andreotti, P. F., et al. (2008). Interactions of Paracoccidioides brasiliensis with host cells: recent advances. Mycopathologia 165, 237-248. doi: 10.1007/s11046-007-9074-z

Missall, T. A., and Lodge, J. K. (2005). Thioredoxin reductase is essential for viability in the fungal pathogen Cryptococcus neoformans. Eukaryot Cell 4, 487-489. doi: 10.1128/EC.4.2.487-489.2005

Moscardi-Bacchi, M., Brummer, E., and Stevens, D. A. (1994). Support of Paracoccidioides brasiliensis multiplication by human monocytes or macrophages: inhibition by activated phagocytes. J. Med. Microbiol. 40, 159164. doi: 10.1099/00222615-40-3-159

Munoz, J. F., Farrer, R. A., Desjardins, C. A., Gallo, J. E., Sykes, S., Sakthikumar, S., et al. (2016). Genome diversity, recombination, and virulence across the major lineages of Paracoccidioides. mSphere 1:e00213-16.

Murad, A. M., and Rech, E. L. (2012). NanoUPLC-MSE proteomic data assessment of soybean seeds using the Uniprot database. BMC Biotechnol. 12:82. doi: 10. $1186 / 1472-6750-12-82$
Murad, A. M., Souza, G. H., Garcia, J. S., and Rech, E. L. (2011). Detection and expression analysis of recombinant proteins in plant-derived complex mixtures using nanoUPLC-MS(E). J. Sep. Sci. 34, 2618-2630. doi: 10.1002/jssc.201100238

Nishikaku, A. S., Molina, R. F., Albe, B. P., Cunha Cda, S., Scavone, R., Pizzo, C. R., et al. (2011). Immunolocalization of IFN- $\gamma$ in the lesions of resistant and susceptible mice to Paracoccidioides brasiliensis infection. FEMS Immunol. Med. Microbiol. 63, 281-288. doi: 10.1111/j.1574-695X.2011.00851.x

Nunnari, J., and Suomalainen, A. (2012). Mitochondria: in sickness and in health. Cell 148, 1145-1159. doi: 10.1016/j.cell.2012.02.035

Parente, J. A., Salem-Izacc, S. M., Santana, J. M., Pereira, M., Borges, C. L., Bailao, A. M., et al. (2010). A secreted serine protease of Paracoccidioides brasiliensis and its interactions with fungal proteins. BMC Microbiol. 10:292. doi: 10.1186/ 1471-2180-10-292

Parente-Rocha, J. A., Parente, A. F., Baeza, L. C., Bonfim, S. M., Hernandez, O., McEwen, J. G., et al. (2015). Macrophage interaction with Paracoccidioides brasiliensis yeast cells modulates fungal metabolism and generates a response to oxidative stress. PLoS One 10:e0137619. doi: 10.1371/journal.pone.0137619

Philippe, B., Ibrahim-Granet, O., Prevost, M. C., Gougerot-Pocidalo, M. A., Sanchez Perez, M., Van der Meeren, A., et al. (2003). Killing of Aspergillus fumigatus by alveolar macrophages is mediated by reactive oxidant intermediates. Infect. Immun. 71, 3034-3042. doi: 10.1128/IAI.71.6.3034-3042.2003

Pigosso, L. L., Baeza, L. C., Tomazett, M. V., Faleiro, M. B. R., Moura, V. M. B. D., Bailão, A. M., et al. (2017). Paracoccidioides brasiliensis presents metabolic reprogramming and secretes a serine proteinase during murine infection. Virulence 8, 1417-1434. doi: 10.1080/21505594.2017.1355660

Price, M. S., Betancourt-Quiroz, M., Price, J. L., Toffaletti, D. L., Vora, H., Hu, G., et al. (2011). Cryptococcus neoformans requires a functional glycolytic pathway for disease but not persistence in the host. mBio 2:e0103-11. doi: 10.1128/ mBio.00103-11

Ramirez, M. A., and Lorenz, M. C. (2007). Mutations in alternative carbon utilization pathways in Candida albicans attenuate virulence and confer pleiotropic phenotypes. Eukaryot Cell 6, 280-290. doi: 10.1128/EC.00372-06

Rodrigues, D. R., Dias-Melicio, L. A., Calvi, S. A., Peracoli, M. T., and Soares, A. M. (2007). Paracoccidioides brasiliensis killing by IFN- $\gamma$, TNF-alpha and GMCSF activated human neutrophils: role for oxygen metabolites. Med. Mycol. 45, 27-33. doi: 10.1080/13693780600981676

Roetzer, A., Gratz, N., Kovarik, P., and Schuller, C. (2010). Autophagy supports Candida glabrata survival during phagocytosis. Cell Microbiol. 12, 199-216. doi: $10.1111 / j .1462-5822.2009 .01391 . x$

Seider, K., Gerwien, F., Kasper, L., Allert, S., Brunke, S., Jablonowski, N., et al. (2014). Immune evasion, stress resistance, and efficient nutrient acquisition are crucial for intracellular survival of Candida glabrata within macrophages. Eukaryot Cell 13, 170-183. doi: 10.1128/EC.00262-13

Seider, K., Heyken, A., Luttich, A., Miramon, P., and Hube, B. (2010). Interaction of pathogenic yeasts with phagocytes: survival, persistence and escape. Curr. Opin. Microbiol. 13, 392-400. doi: 10.1016/j.mib.2010.05.001

Souto, J. T., Aliberti, J. C., Campanelli, A. P., Livonesi, M. C., Maffei, C. M., Ferreira, B. R., et al. (2003). Chemokine production and leukocyte recruitment to the lungs of Paracoccidioides brasiliensis-infected mice is modulated by interferon-gamma. Am. J. Pathol. 163, 583-590. doi: 10.1016/S0002-9440(10) 63686-3

Souto, J. T., Figueiredo, F., Furlanetto, A., Pfeffer, K., Rossi, M. A., and Silva, J. S. (2000). Interferon-gamma and tumor necrosis factoralpha determine resistance to Paracoccidioides brasiliensis infection in mice. Am. J. Pathol. 156, 1811-1820. doi: 10.1016/S0002-9440(10) 65053-5

Sprenger, M., Kasper, L., Hensel, M., and Hube, B. (2017). Metabolic adaptation of intracellular bacteria and fungi to macrophages. Int. J. Med. Microbiol. doi: 10.1016/j.ijmm.2017.11.001 [Epub ahead of print].

Szilagyi, M., Miskei, M., Karanyi, Z., Lenkey, B., Pocsi, I., and Emri, T. (2013). Transcriptome changes initiated by carbon starvation in Aspergillus nidulans. Microbiology 159, 176-190. doi: 10.1099/mic.0. 062935-0

Teixeira, M. M., Theodoro, R. C., de Carvalho, M. J., Fernandes, L., Paes, H. C., Hahn, R. C., et al. (2009). Phylogenetic analysis reveals a high level of speciation in the Paracoccidioides genus. Mol. Phylogenet. Evol. 52, 273-283. doi: 10.1016/ j.ympev.2009.04.005 
Turissini, D. A., Gomez, O. M., Teixeira, M. M., McEwen, J. G., and Matute, D. R. (2017). Species boundaries in the human pathogen Paracoccidioides. Fungal Genet. Biol. 106, 9-25. doi: 10.1016/j.fgb.2017.05.007

Yin, Z., Stead, D., Selway, L., Walker, J., Riba-Garcia, I., McLnerney, T., et al. (2004). Proteomic response to amino acid starvation in Candida albicans and Saccharomyces cerevisiae. Proteomics 4, 2425-2436. doi: 10.1002/pmic. 200300760

Yoshida, T., Oka, S., Masutani, H., Nakamura, H., and Yodoi, J. (2003). The role of thioredoxin in the aging process: involvement of oxidative stress. Antioxid. Redox Signal. 5, 563-570. doi: 10.1089/1523086037703 10211
Conflict of Interest Statement: The authors declare that the research was conducted in the absence of any commercial or financial relationships that could be construed as a potential conflict of interest.

Copyright (c) 2019 Chaves, Parente-Rocha, Baeza, Araújo, Borges, Oliveira and Soares. This is an open-access article distributed under the terms of the Creative Commons Attribution License (CC BY). The use, distribution or reproduction in other forums is permitted, provided the original author(s) and the copyright owner(s) are credited and that the original publication in this journal is cited, in accordance with accepted academic practice. No use, distribution or reproduction is permitted which does not comply with these terms. 